Bangladesh J. Bot. 48(2): 239-251, 2019 (June)

\title{
ISOLATION AND IDENTIFICATION OF AZOSPIRILLUM AND AZOTOBACTER SPECIES FROM ACACIA SPP. AT RIYADH, SAUDI ARABIA
}

\author{
Kamal Hassan Sulaiman, Fahad Nasser Al-Barakah, Abdulaziz Muhammad \\ Assaeed $^{1 *}$ and Basharat Ali Muhammad Dar ${ }^{1}$
}

Department of Soil Sciences, College of Food and Agriculture Sciences, King Saud University, P.O. Box; 2640, Riyadh, Saudi Arabia

Keywords: Isolation, Identification, Azospirillum, Azotobacter, Acacia

\begin{abstract}
Populations of Azospirillum and Azotobacter isolated and identified from the soil rhizosphere of Acacia ehernbergiana, A. gerrardii and A. tortilis from three sites varied widely irrespective of tree species, size and site. Azospirillum strains were purified and characterized through morphological, microscopic and biochemical tests for motility, cell shape, pigmentation, colony color, gram reaction, optimal temperatures, biotin requirement, $\mathrm{pH}$ growth, acidification of peptone glucose medium, ability of nitrogen fixation, growth on $3 \% \mathrm{NaCl}$, and D-glucose and D-ribose utilization. Twenty Azospirillum isolates were divided into four matching characters. They were identified as A. lipoferum, A. brasilense, A. dobereinerae and A. zeae. The same above tests with omission of temperatures, biotin requirement, and acidification of peptone and addition of starch hydrolysis, $\mathrm{H}_{2} \mathrm{~S}$, urease, oxidase and sucrose, maltose and mannitol as carbon source were applied to Azotobacter strains. Azotobacter isolates were divided into three matching characters. They were identified as A. chroococcum, A. beijerinckii and A. salinestris.
\end{abstract}

\section{Introduction}

Biological nitrogen fixation is one of the most important biological processes in nature. The utilization of biological nitrogen fixation technology can also decrease the use of urea-N, prevent depletion of soil organic matter and reduce environmental pollution to a considerable extent (Bhardwaj et al. 2014). Diazotrophic -associated bacteria plays a key role in plant growth, development and nutrition by numerous mechanisms (Glick 2012). Application of biofertilizers scan decrease the use of chemical fertilizers and also can increase the yield of crops (Bhardwaj et al. 2014, Ajmal et al. 2018). Among N-fixing bacteria, Azospirillum and Azotobacter spp. have high adaptation ability to colonize different host plants and have been isolated from numerous geographical regions of the world (Upadhyay et al. 2015). The two genera are known to be associated with roots of various wild and cultivated plant species and soils of several regions and may increase the crop yield up to 30\% (Saharan and Nehra 2011). Currently the genus Azospirillum is comprised of 10 species, including A. amazonense and A. doebereinerae (Lavrinenko et al. 2010).

Azospirillum colonizes the root region of crop plants in large numbers and fixes substantial amount of nitrogen (Saikia et al. 2013). Crop production response to bacteria with Azospirillum inoculants was almost equivalent to that of application of $15-20 \mathrm{~kg} \mathrm{~N} / \mathrm{ha}$ (Hossain et al. 2014). Inoculation with Azospirillum brasilense increased grain production of maize (Morais et al. 2016). Further, Azospirillum also produces growth regulating substances (Bashan and de-Bashan 2010). Moreover, inoculation with A. brasilense was effective in elevating endogenous nutrient content

*Author for correspondence: <assaeed@ksu.edu.sa>. ${ }^{1}$ Department of Plant Production, College of Food and Agriculture Sciences, King Saud University, P.O. Box; 2640, Riyadh, Saudi Arabia. 
in rice plants and improved its growth and yield (Sahoo et al. 2014). Azospirillum brasilense and A. lipoferum were isolated from roots of wheat cultivars (Rojas et al. 2013) indicating the potential of these two isolates in fixing nitrogen in most species.

The genus Azotobacter is comprised of seven species, including A. chroococcum and A. vinelandii (Mazinani and Asgharzadeh 2014). Azotobacters have extremely high respiration rates and it was estimated that with its inoculation, the total benefit to crops and soil was $73.8 \mathrm{~kg}$ $\mathrm{N} / \mathrm{ha} / \mathrm{yr}$ after one soybean-wheat rotation (Rawat et al. 2012).

Both Azospirillum lipoferum and Azotobacter chroococcum can improve seed tolerance of Dodonaea viscosa L. to salinity and increase its germination percentage (Yousefi et al. 2017). In a study on $\mathrm{N}$-fixing bacterial endophyte diversity associated with A. ehrenbergiana and A. tortilis in a desert region, Boukhatem et al. (2016) indicated that the isolated nodular endophytes revealed strong tolerance to salinity and high temperature. Similarly, Alnohait (2015) reported Azospirillum and Azotobacter genera in the rhizosphere of A. gerrardii. The objectives of this study were to isolate, characterize and identify Azospirillum sp. and Azotobacter sp. from three Acacia plant species (Acacia tortilis, A. ehrenbergiana and A. gerrardii) of different sizes in Riyadh, Saudi Arabia.

\section{Materials and Methods}

The study was conducted in three sites in Riyadh region, Saudi Arabia viz. Sheibh Washlah $\left(24^{\circ} 26^{\prime} \mathrm{N}, 46^{\circ} 38^{\prime} \mathrm{E}\right)$, Raudhat Khuraim $\left(25^{\circ} 25^{\prime} \mathrm{N}, 47^{\circ} 15^{\prime} \mathrm{E}\right)$ and Sheib Huraymila $\left(25^{\circ} 04^{\prime} \mathrm{N}, 46^{\circ} 03^{\prime} \mathrm{E}\right)$ (Fig. 1). These three sites were referred to as Washlah, Khuraim and Huraymila, respectively. The vegetation of the study area reflects typical desert flora dominated by shrub species (Alatar $e$ al. 2015). Soil physical and chemical properties were fully described by Suliman et al. (2017). Generally, soil ranged from sandy loam to clay loam with slightly alkaline $\mathrm{pH}$. The soils of all studied sites were calcareous in nature and poor in nutrients and organic matter content.

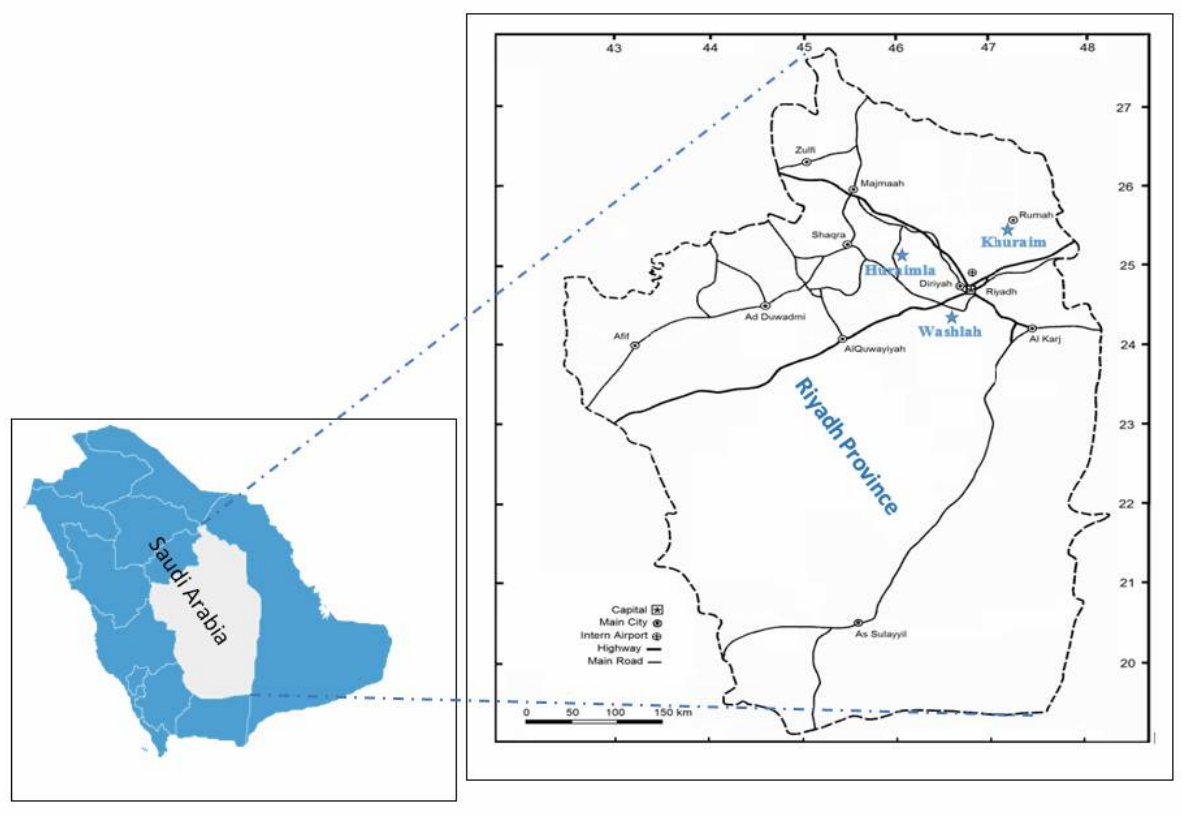

Fig 1. Map of the study site and sampling location. 
Soil rhizosphere samples along with fine roots of Acacia tortilis, A. ehrenbergiana and A. gerrardii were collected during January to March, 2016 from the three sites viz. Washlah, Khuraim and Huraymila of Riyadh region, Saudi Arabia. In Khuraim site, only A. ehrenbergiana and A. gerrardii were found. In each site, Acacias were categorized into three size classes; small (1- $1.5 \mathrm{~m}$ ), medium $(1.5-3 \mathrm{~m}$ ) and large (more than $3 \mathrm{~m}$ high). From each site, three soil samples were collected from the root rhizosphere of the different size classes of the three species. Also, three soil samples away from the root rhizosphere (free soil) were also collected from each site. Samples were wrapped in polyethylene bags in ice box and brought to the laboratory.

Different isolation methods were used to isolate indigenous Azospirillum and Azotobacter species from Acacia rhizosphere. A subsample of $10 \mathrm{~g}$ of soil was used for serial dilution method. Azospirillum sp. was isolated in screw cap tubes containing approximately5ml sterilized semisolid N-free malate medium (L-malic $5 \mathrm{~g}, \mathrm{~K}_{2} \mathrm{HPO}_{4} 0.5 \mathrm{~g}, \mathrm{MgSO}_{4} .7 \mathrm{H}_{2} 00.2 \mathrm{~g}, \mathrm{NaCl} 0.02 \mathrm{~g}$, trace element solution $2 \mathrm{ml}$, bromthymol blue ( $0.5 \%$ dissolve in $\mathrm{KOH}) 2 \mathrm{ml}$; Fe EDTA (1.64\% solution) $4 \mathrm{ml}, \mathrm{KOH} 4 \mathrm{~g}$, Agar $1.75 \mathrm{~g}$, final $\mathrm{pH} 6.8$ with $\mathrm{KOH}$ ) for solid medium added $15 \mathrm{~g} / \mathrm{l}$ ) (Usha and Kanimozhi 2011) under aseptic conditions. The tubes were incubated at $28^{\circ} \mathrm{C}$ for two weeks and observed for growth of Azospirillum as subsurface pellicle.

For enrichment, semi-solid NFb medium was used and streaked on the plates of SOLID NFb medium containing $0.02 \mathrm{~g} / \mathrm{l}$ yeast extract of A. brasilense, A. lipoferum and A. doebereinerae and A. zeae were incubated on $\mathrm{M}$ medium without biotin $\left(5.0 \mathrm{~g}\right.$ sodium malate, $0.02 \mathrm{~g} \mathrm{CaCl}_{2} .2 \mathrm{H}_{2} \mathrm{O}$, $0.2 \mathrm{~g} \mathrm{MgSO}_{4} .7 \mathrm{H}_{2} \mathrm{O}, \quad 0.1 \mathrm{~g} \mathrm{~K}_{2} \mathrm{HPO}_{4}, \quad 0.4 \mathrm{~g} \mathrm{KH}_{2} \mathrm{PO}_{4}, 0.1 \mathrm{~g} \mathrm{NaCl}, 10 \mathrm{mg} \mathrm{FeCl}_{3}, 2$ $\mathrm{mgNa}_{2} \mathrm{MoO}_{4} .2 \mathrm{H}_{2} \mathrm{O}, 0.1 \mathrm{~g}$ yeast extract, 1.01 distilled water, $\mathrm{pH}$ 6.8) (Xie and Yokota 2005) and basal medium with sucrose (BMS) agar per 1 lire distilled water (potatoes $200 \mathrm{~g}$, L-malic acid 2.5 $\mathrm{g}, \mathrm{KOH} 2.0 \mathrm{~g}$, raw cane sugar $2.6 \mathrm{~g}$, vitamin solution $1.0 \mathrm{ml}$ bromthymol blue $(0.5 \%$ alcoholic solution) 2 drops and agar $(15 \mathrm{~g})$.

Streaking of serial soil dilution was performed on plates containing Ashby Mannitol Agar (per 11): 20 g mannitol, $0.2 \mathrm{~g} \mathrm{~K}_{2} \mathrm{HPO}_{4}, 0.2 \mathrm{~g} \mathrm{MgSO}_{4} .7 \mathrm{H}_{2} \mathrm{O}, 0.2 \mathrm{~g} \mathrm{NaCl}, 0.1 \mathrm{~g} \mathrm{~K}_{2} \mathrm{SO}_{4}, 5 \mathrm{~g} \mathrm{CaCO}_{3}, 15 \mathrm{~g}$ agar (Hi-Media Laboratories Pvt. Ltd. Mumbai, India) (Mazinani et al. 2012, Ahmad et al. 2016). Enrichment on Burk's Medium has the following composition: (g/l) $\mathrm{K}_{2} \mathrm{HPO}_{4} 0.64, \mathrm{KH}_{2} \mathrm{PO}_{4}$ 0.2, $\mathrm{MgSO}_{4} .7 \mathrm{H}_{2} \mathrm{O} 0.2, \mathrm{NaCl}_{2} 0.2, \mathrm{CaSO}_{4} .2 \mathrm{H}_{2} \mathrm{O} 0.05, \mathrm{Na}_{2} \mathrm{MoO}_{4}$ 0.001, $\mathrm{FeSO}_{4} 0.003$, sucrose 20 sterilized separately, agar $1.5 \%$ (W/V), followed by streaking on to Ashby Mannitol Agar. The plates were incubated at $28^{\circ} \mathrm{C}$ for 3-7 days presenting growth of Azotobacter were revealed by the appearance of smooth, opaque, low convex, mucoid slimy and glistening colonies.

Enumeration of microorganisms in soil samples were carried out by most probable number (MPN). One milliliter successive dilutions of $10^{3}, 10^{4}, 10^{5}$ soil samples were transferred to the test tube containing semi-solid $\mathrm{NFb}$ medium and plates of Ashby medium for Azospirillum and Azotobacter isolates, respectively. Tubes and plates were then incubated under suitable temperature.

$$
\text { Bacterial population }=\frac{\text { MPN value } \times \text { middle dilution } \times \text { middle dilution used }}{\text { Dry weight of the soil sample }}
$$

Microorganisms were identified based on cultural, morphological and biochemical characteristics as per Bergey's Manual of Systematic Bacteriology. Motility, cell shape, color, consistency and gram stain were described for morphological characterization of bacterial isolates. Motility of Azospirillum and Azotobacter isolates were tested by hanging drop method (Narendran et al. 2016). Slides were prepared with cultures and motility was observed under oil immersion.

Different biochemical tests were performed, and the protocols followed are briefly outlined below. 
The biotin requirements of the Azospirillum isolates were tested using semi-solid nitrogenfree malic acid medium prepared in two sets of tubes; one set of medium prepared with the addition of biotin $(100 \mu \mathrm{g} / \mathrm{l})$ and the other without biotin. The growth was observed by the change in color from yellowish green to blue (Chari et al. 2015)

Azospirillum isolates were tested by the method of (Garrity et al. 2005). The medium composition was as follows (g/l): peptone 2.0, $\left(\mathrm{NH}_{4}\right)_{2} \mathrm{SO}_{4} 1.0, \mathrm{MgSO}_{4 \cdot 7} \mathrm{H}_{2} \mathrm{O} 1.0, \mathrm{FeCl}_{3} \cdot 6 \mathrm{H}_{2} \mathrm{O}$ $0.002, \mathrm{MnSO}_{4} \cdot \mathrm{H}_{2} \mathrm{O} 0.002$, bromothymol blue 0.025 , (Dissolved in dilute $\mathrm{KOH}$ ). The medium was made up to the volume of $950 \mathrm{ml}$, the $\mathrm{pH}$ was adjusted to 7.0 and sterilized by autoclaving at 15 lbs for 20 minutes. After cooling, $50 \mathrm{ml}$ of $20 \%$ (W/V) solution of glucose (sterilized by filtration) was added aseptically. The medium was inoculated with a loopful of $24 \mathrm{hrs}$ culture from semisolid $\mathrm{Nfb}$ malate medium. The tubes were incubated at $30^{\circ} \mathrm{C}$ for $96 \mathrm{hrs}$. The development of yellow color was observed after incubation period.

For the determination of the efficiency of $\mathrm{N}_{2}$ fixation of Azospirillum, isolates were grown in semi-solid $\mathrm{Nfb}$ medium to fix nitrogen. A loopful of the pure culture was inoculated into test tubes containing $10 \mathrm{ml}$ of sterilized in semi-solid $\mathrm{Nfb}$ malate medium. Non-inoculated test tubes containing the same medium served as control. All the tubes (duplicate for each strain) were incubated at $30^{\circ} \mathrm{C}$ for 10 to 15 days. Total amount of $\mathrm{N}_{2}$ fixed by each isolate was expressed as $\mathrm{mg}$ $\mathrm{N} / \mathrm{g}$ of malate after deducting the amount of nitrogen in control samples. The distillate was collected into $10 \mathrm{ml} \mathrm{3 \%}$ boric acid solution having bromocresol green and methyl red mixed indicator. Final samples were titrated against $0.01 \mathrm{~N}$ sulphuric acid.

Azotobacter isolates were grown in sterilized $10 \mathrm{ml}$ Ashby medium (without agar) in $20 \mathrm{ml}$ test tube on a rotary shaker $(125 \mathrm{rpm})$ under continuous airflow at $30^{\circ} \mathrm{C}$ for 72 . Cell concentrations were determined as $10^{6} \mathrm{CFU} / \mathrm{ml}$ of each isolate. The non-inoculated media served as control. Nitrogen was determined by micro-Kjeldahl analysis (Kanimozhi and Panneerselvam 2010).

The amount of total nitrogen in the sample was calculated by using the formula:

Total nitrogen $=\frac{(\mathrm{ml} \text { standard acid }-\mathrm{ml} \text { blank }) \times \mathrm{N} \text { of acid } \times 1.4007}{\text { Weight of sample in grams }}$

Only Azospirillum isolates were grown on semi-solid $\mathrm{Nfb}$ malate medium having concentration of sodium chloride $3 \%$ for growth ability test.

For carbon utilization, a loopful of Azospirillum culture was grown at semi-solid $\mathrm{Nfb}$ malate medium having $1.0 \%$ replaced of D-glucose and D-ribose which were sterilized separately by filtration. The development of yellow color was observed after incubation period. For the Azotobacter bacteria isolates, sucrose, maltose and mannitol were used. The test was done following the method described by Garrity et al. (2005). Sterilized screw tube with Durham tube contained $5 \mathrm{ml}$ of the phenol red carbohydrate broth medium composed $(\mathrm{g} / \mathrm{l})$ : protase peptone 10 , $\mathrm{NaCl} 5$, beef extract 1.0, phenol red 0.018 and carbohydrate 10.0 used single carbohydrate for each test. Tubes were inoculated with bacteria growth and incubated under $28^{\circ} \mathrm{C}$ for $18-48 \mathrm{hrs}$. Gas production indicates positive results and reddish or pink color indicates negative results.

Mannitol test was done following the methods of Hi-Media Laboratories Pvt. Ltd. Technical data (Atlas 2010), phenol red mannitol broth medium was composed (g/l) of Protase peptones 10, According to beef extract 1.0, mannitol 5.0, $\mathrm{NaCl} 5$, phenol red 0.018, $\mathrm{pH} 7.4 .5 \mathrm{ml}$ of the medium in sterilized screw tube with Durham tube. Tubes were inoculated and incubated under $28^{\circ} \mathrm{C}$ at 18 - $48 \mathrm{hrs}$. Gas production indicates positive. 
Tolerance to high temperature was tested by growing Azospirillum isolates on semi-solid $\mathrm{Nfb}$ malate medium and incubation at 30,37 and $41^{\circ} \mathrm{C}$ for $24 \mathrm{hrs}$ and then inoculation and incubation at $30^{\circ} \mathrm{C}$ for $72 \mathrm{hrs}$ on solid $\mathrm{Nfb}$ malate medium plates.

The production of diffusible pigments in the presence or absence of the Azotobacter bacteria isolates was done following the method of Jiménez et al. (2011) the basal medium composed (g/l): $\mathrm{K}_{2} \mathrm{HPO}_{4}$ 1.0, $\mathrm{CaCl}_{2 \cdot 2} \mathrm{H}_{2} \mathrm{O} 0.1, \mathrm{MgSO}_{4 \cdot 7} \mathrm{H}_{2} \mathrm{O}$ 0.2, and $\mathrm{NaMoO}_{4} \cdot 2 \mathrm{H}_{2} \mathrm{O} 0.005$, Ion agar 10.0, glucose 10.0 and $\mathrm{pH} 7.3$.

Starch hydrolysis test of Azotobacter sp. was done following the methods of Akhter et al. (2012) on starch agar plates. Plates were inoculated by streak method and incubated at $30^{\circ} \mathrm{C}$ for 24 hrs. After growth, iodine solution was added. Blue color with clear halos surroundings bacteria growth indicates positive results and blue color without clear halos designates negative results.

The test of hydrogen sulfide for Azotobacter isolates was done according to Cappuccino and Welsh (2017). Isolates were cultured on slant of triple sugar iron (TSI) agar medium. Streaked TSI slant with growth culture was incubated at $28^{\circ} \mathrm{C}$ for $24 \mathrm{hrs}$. Slant has black color in butt indicates that positive results (hydrogen sulfide) red or orange slant color negative results.

Oxidase test for isolated Azotobacter sp. was measured by the method of Naz et al. (2012). Small piece of sterilized filter paper was moistened with $1-2$ drops of oxidase reagent. Sterilized loopful of colony was touched with filter paper under aseptically condition. Blue color after 10 - $30 \mathrm{sec}$ indicates positive results and no change designates negative results.

Azotobacter isolates urease activity test was measured by the method of Rasool et al. (2015). Urea broth medium (yeast extract $0.1 \mathrm{~g}, \mathrm{KH}_{2} \mathrm{PO}_{4} 9.1 \mathrm{~g}, \mathrm{~K}_{2} \mathrm{HPO}_{4} 9.5 \mathrm{~g}$, phenol red $0.01 \mathrm{~g}$ ) was inoculated with test organism and incubated at $30^{\circ} \mathrm{C}$ for $24-72 \mathrm{hrs}$.

For temperature tolerance, fresh culture colony of Azotobacter sp. was taken by sterilized loop and inoculated to sterilized test tubes which were filled with Azotobacter broth medium composed $(\mathrm{g} / \mathrm{l}): \quad \mathrm{K}_{2} \mathrm{HPO}_{4} \quad 0.8, \quad \mathrm{KH}_{2} \mathrm{PO}_{4} \quad 0.2, \quad \mathrm{MgSo}_{4 \cdot 7} \mathrm{H}_{2} \mathrm{O} \quad 0.5, \quad \mathrm{FeSo}_{4 \cdot 6} \mathrm{H}_{2} \mathrm{O} \quad 0.1, \quad \mathrm{CaCl}_{2 \cdot 2} \mathrm{H}_{2} \mathrm{O} \quad 0.05$, $\mathrm{NaMoO}_{4 \cdot 2} \mathrm{H}_{2} \mathrm{O} 0.05$, pH 7.5 and incubated at 32 and $37^{\circ} \mathrm{C}$ for $24 \mathrm{hrs}$. Then inoculating and incubated at $30^{\circ} \mathrm{C}$ for $3-5$ days on Ashby's mannitol agar medium plates.

\section{Results and Discussion}

Several types of microorganisms were isolated from soil rhizosphere samples of three size classes of three different acacia species. Identification of Azospirillum and Azotobacter were based on growth cultural, morphological and biochemical characteristics of isolates (Table 1 and Fig. 2A, B-F). These bacteria were transferred successively to solid (N-free) media and purified.

In these experiments, 27 Azospirillum isolates were screened for their efficiency using various biochemical tests. Growth of Azospirillum was observed as the appearance of a thin white colored pellicle below the surface of the semi-solid $\mathrm{Nfb}$ malate medium, then transferred into $\mathrm{NFb}$ agar plates and $\mathrm{M}$ medium. Colonies formed in this medium were initially yellowish white, and eventually became pinkish, grey and pink colonies form after $48-72 \mathrm{hrs}$, become wrinkled and dried with time on M medium.

For enumeration of population density, the number of colonies was counted in range of (0.11 $\times 10^{2}-33 \times 10^{2} \mathrm{CFU} / \mathrm{g}$ soil) (Fig. $3 \mathrm{~A}, \mathrm{~B}$ and C). The highest population density was shown in small-size A. ehernbergiana and the lowest population density was observed in free soil at Khuraim site.

Microscopic examination of Azospirillum isolates revealed that they were pleomorphic forms, vibrioid, slightly curved rods in shape and motility levels of all isolates showed spiral, single polar flagellum and winding or snake-like movement. Based on the staining, all isolates were Gram- 


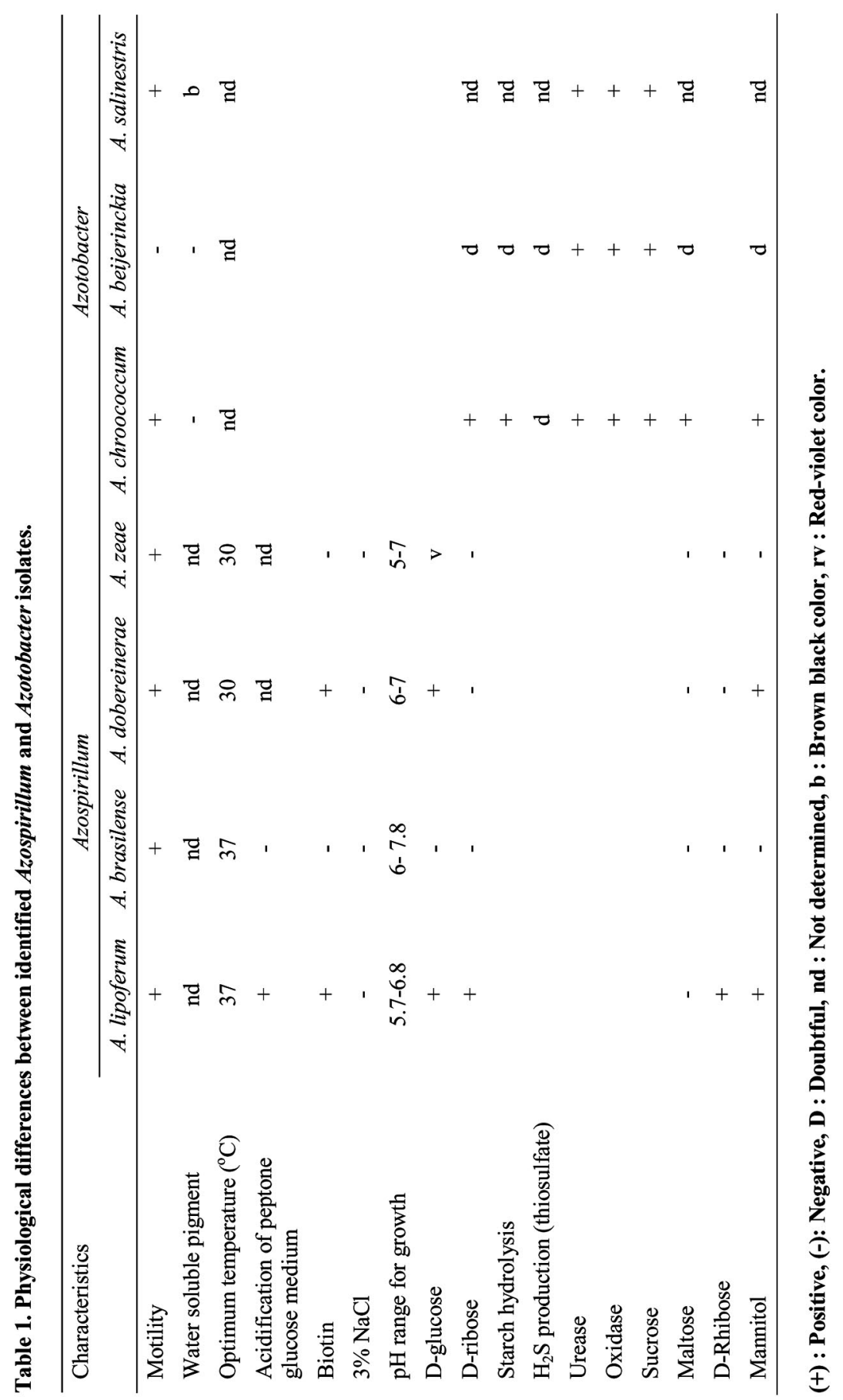


negatives which are characteristics of genus Azospirillum (Cassán et al. 2015). The efficiency strains of Azospirillum sp. to utilize carbon was tested as per the procedures described earlier. Isolates grew in D-glucose and D-ribose (1\%) utilization test using semi-solid $\mathrm{Nfb}$ malate medium (without malate), turned to yellow color after incubation period. Some strains showed no change in the medium color and grew well in the medium containing biotin (Pandiarajan et al. 2012). Strain showed positive growth in the peptone-based glucose which turned the medium to yellow color due to acidification after 24-96 hrs of incubation time. In BMS, the colonies formed became pinkish as they grew larger. Some isolates were salt tolerant up to $3 \% \mathrm{NaCl}$ at the same way of Akhter et al. (2012) who reported that $\mathrm{N}$-fixing bacteria tolerated $6 \% \mathrm{NaCl}$. Having optimal temperature of $37^{\circ} \mathrm{C}$, pleomorphic cells (S-shape or helical), non-motile with $48 \mathrm{hrs}$ and vibrioid,

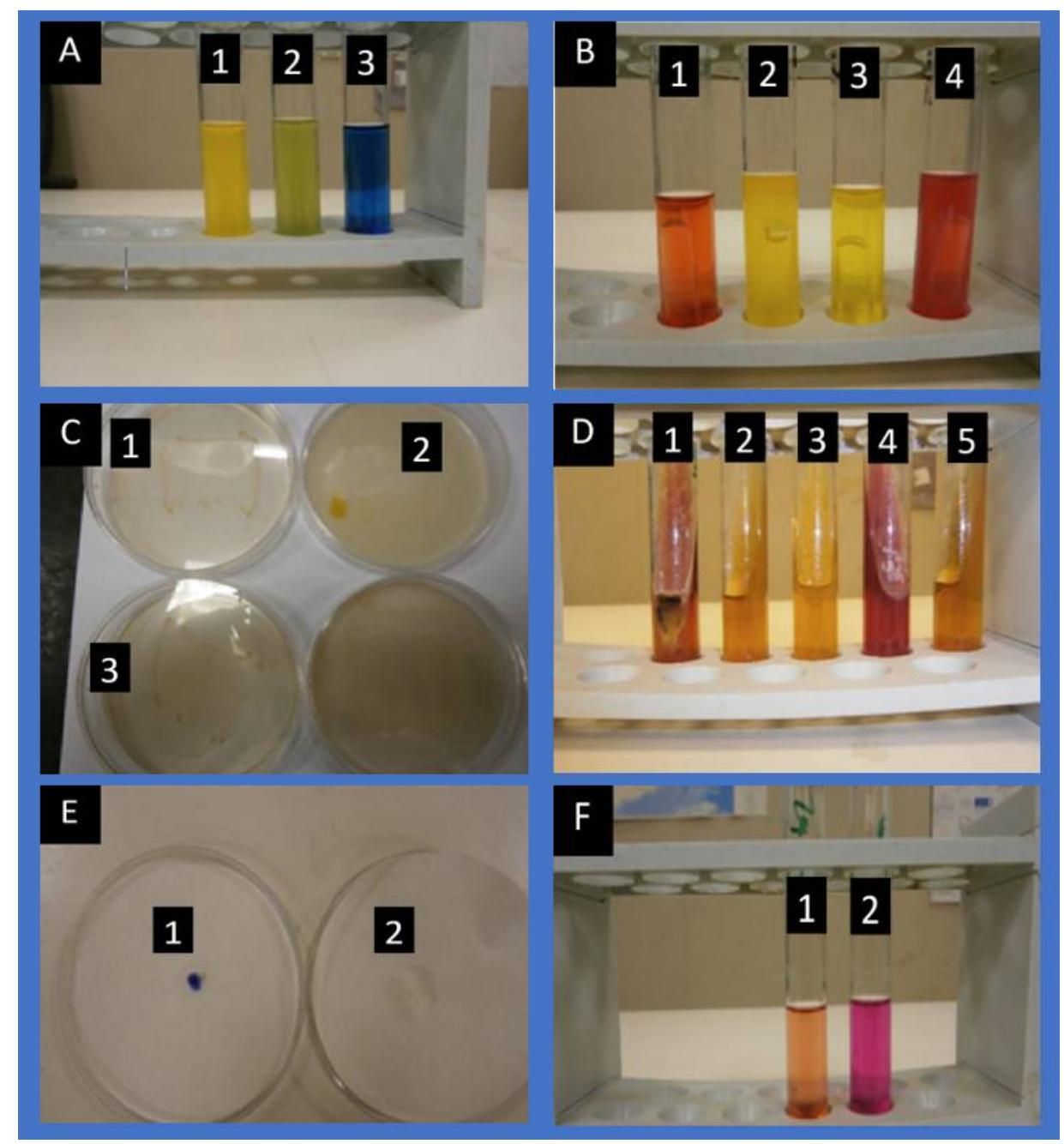

Fig. 2 (A) Acidification peptone glucose: 1, 2 positive, 3 negative, (B) sucrose utilization: 1 control, 2 positive with gas, 3 positive without gas, 4 negative, (C) pigments: 1,3 brown black, 2 yellowish green, (D) $\mathrm{H}_{2} \mathrm{~S}$ produced 1, red slant re red butt $\mathrm{H}_{2} \mathrm{~S}$ formed, 2, 3 yellow slant, 4 red butt red slant, 5 control (E) oxidase test 1 positive, 2 negative and $(\mathrm{F})$ urease 1 , negative 2, positive. 


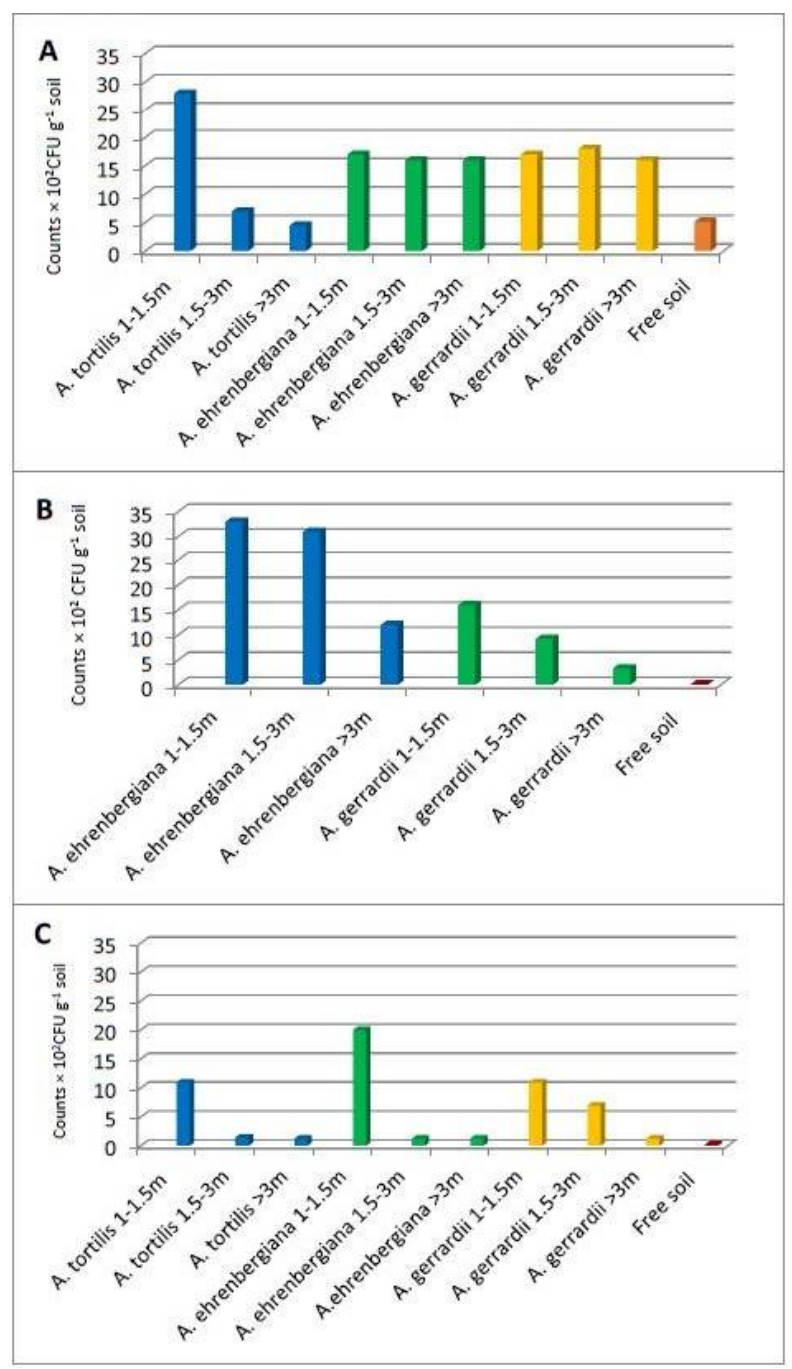

Fig. 3. A, B and C. Azospirillum density counts (CFU/g soil) in Acacia rhizosphere at A. Washlah, B. Khuraim and C. Huraymila sites.

and curved rods in alkaline medium ( $\mathrm{pH}$ for growth $5.7-7.8$ ), the strains were identified as $A$. lipoferum and A. brasilense as reported by (Raffi and Charyulu 2012). Some strains were characterized by $30^{\circ} \mathrm{C}$ optimal temperature, failed to grow in $3 \% \mathrm{NaCl}$, not requiring biotin for growth, $\mathrm{pH}$ growth $6.0-7.0$, no acidification of peptone-based glucose and D-glucose or Dribose, curved rods or S-shaped and motile with a winding or snake-like movement. These strains were identified as A. dobereinerae and were similar to the findings of Eckert et al. (2001). Those strains having rod cells, motile with a single polar flagellum, formed pink pigment colonies after 48-72 hrs, became wrinkled and dried with time. Their optimum growth on $\mathrm{M}$ medium occurred at $30^{\circ} \mathrm{C}$ and $\mathrm{pH}$ 5-7 but failed to grow in $3 \% \mathrm{NaCl}$. They were negative for D-ribose and D-glucose and had negative growth in medium containing biotin. They were identified as A. zeae according to the criteria of Reis et al. (2015). Among 27 tested isolates, 7 were identified as Enterobacter sp. and 
Benibacillus sp. They were not processed further. The remaining 20 isolates were identified as Azospirillum and were divided into 4 categories depending on the characterizations and were identified as A. lipoferum, A. brasilense, A. dobereinerae and A. zeae (Table 1).

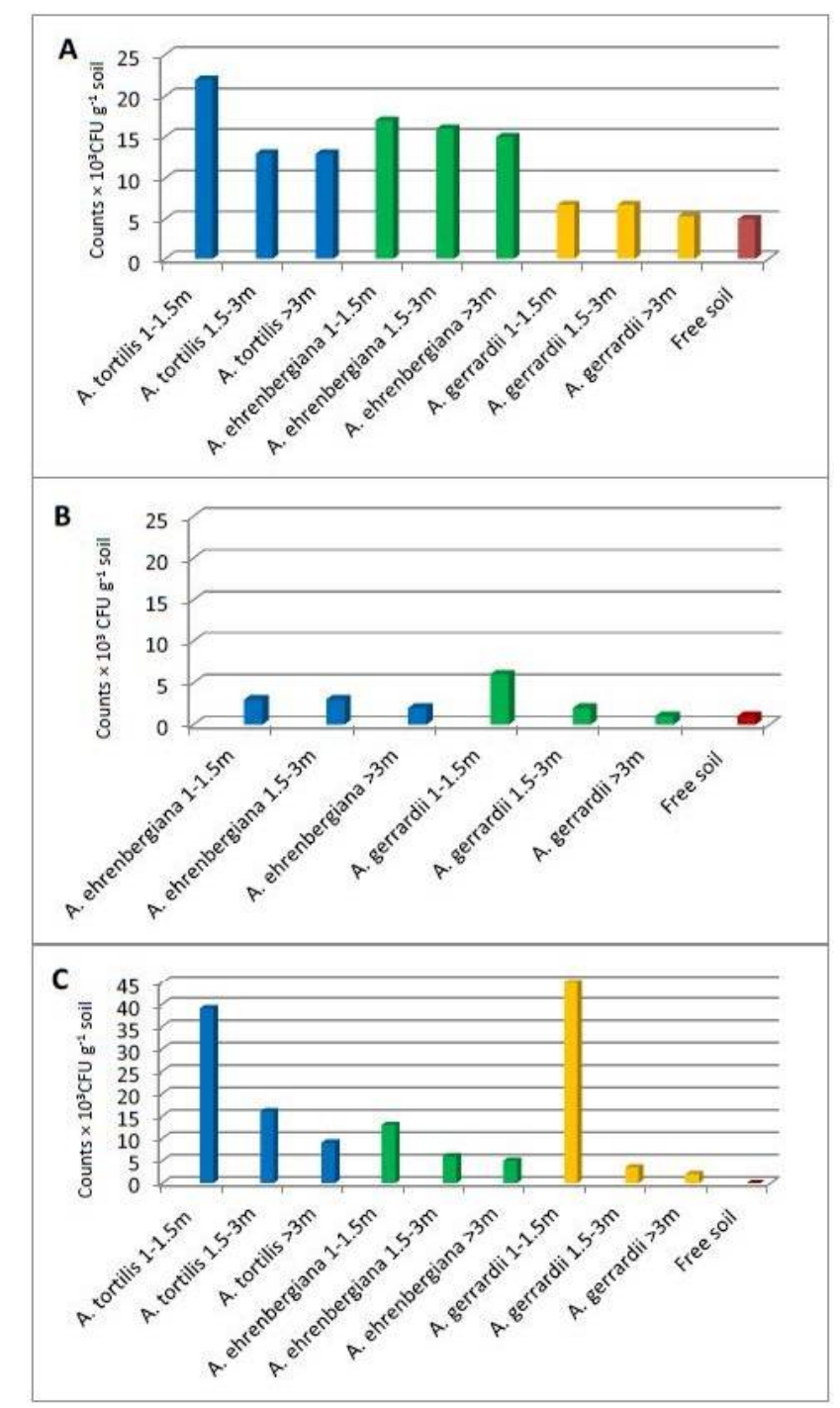

Fig. 4. A, B and C. Azotobacter density counts (CFU/g soil) in Acacia rhizosphere at A. Washlah, B. Khuraim and C. Huraymila.

For Azotobacter isolates, from the total of 27 soil samples were tested using various characterizations and biochemical tests. Growth of Azotobacter sp. was observed as an appearance of slimy, glistening, opaque, convex, smooth, mucoid and oval in $\mathrm{N}$-free Ashby mannitol agar. From the census of population density, the number of colonies was counted in the range of $\left(1 \times 10^{3}-45 \times 10^{3}\right.$ CFU/g soil) (Fig. 4 A, B and C). Abundance was very low possibly due to high 
$\mathrm{pH}$ and low organic matter content in soil. The highest population density was observed in soil rhizosphere of small-size A. gerrardii at Huraymila and the lowest in large sized A. gerrardii at Khuraim. Earlier, Alnohait (2015) recorded Azotobacter sp. in the rhizosphere of A. gerrardii.

Cell morphology appears as rods to ellipsoid and ended-rods. All grown isolates were Gramnegatives. These results are similar to the findings of Akhter et al. (2012). Some isolates were motile, produced $\mathrm{H}_{2} \mathrm{~S}$ on phenol red carbohydrate broth medium containing $1 \%$ sucrose or maltose which agrees with the results obtained by Upadhyay et al. (2015) and Yorukce et al. (2017) who utilized mannitol, starch, urease and oxidase.

Some isolates were non-motile, oval rod shape, smooth colonies, positive reaction of sucrose and negative reaction of maltose and hydrolysis of starch. These results are in alignment with those of Upadhyay et al. (2015). Strains having urease, oxidase positive results, motile by means of peritrichous flagella and oval with pointed ends, utilizing of urease, hydrolysis of starch and sucrose and negative $\mathrm{H}_{2} \mathrm{~S}$ are characteristic features of $A$. beijerinckii. The characters of isolates were also similar to those of A. salinestris (Patel et al. 2013). Depending on characterization, isolates were identified as A. chroococcum, A. beijerinckii and A. Salinestris (Table 1). All isolated strains had nitrogen fixing efficiency. Stella and Suhaimi (2010) also reported that among the Azotobacter, A. chroococcum, A. vinelandii and A. beijerinckii exhibited high growth, nitrogen fixation and in vitro production of phytohormone.

Among the 27 soil sample isolates, 19 were belonged to Azotobacter and the remaining 8 were Sinorhizobium sp., Mesorhizobium sp. and Bacillus sp. They were omitted and were not processed further. Azotobacter species which has the same characters were placed in one category and were identified as A. chroococcum, A. beijerinckii and A. salinestris.

Table 2. Nitrogen fixation by the isolates of Azospirillum sp. and Azotobacter sp.

\begin{tabular}{lc}
\hline Identified isolates & Mg N fixed/g \\
\hline Azospirillum lipoferum & 6.9 \\
A. brasilense & 9.3 \\
A. dobereinerae & 5.4 \\
A. zeae & 3.3 \\
Azotobater chroococcum & 6.3 \\
A. beijerinckia & 7.6 \\
A. salinestris & 2.7 \\
\hline
\end{tabular}

Nitrogen fixing capacity was estimated by Kjeldhal method. Results showed both Azosirillum sp. and Azotobacter sp. have the efficiency to fix nitrogen. The range of nitrogen fixing ability with Azospirillum sp. was between 3.3 to $9.3 \mathrm{mg} \mathrm{N} / \mathrm{g}$. Among them, the maximum nitrogen fixing ability $(9.3 \mathrm{mg} \mathrm{N} / \mathrm{g})$ was recorded from $A$. brasilense and minimum $(3.3 \mathrm{~m} \mathrm{~N} / \mathrm{g})$ was recorded in A. zeae. (Table 2). Among other factors, the nitrogen fixing abilities of Azospirillum isolates depend on nitrogenase enzyme activity (Sant'Anna et al. 2011). Hossain et al. (2014) reported that nitrogen fixing efficiency of Azospirillum sp. ranged from 10.03 to $13.11 \mathrm{mg} \mathrm{N} / \mathrm{g}$. Further, $A$. brasilense had high fixed $\mathrm{N}$ values compared to other species as a result of NifA which is inactive in conditions of excess nitrogen (Lin et al. 2011).

Results showed that pellicles were greater in roots than in the soil samples which agrees with the findings of da Silva et al. (2014). In general, Azospirillum isolates showed higher $\mathrm{N}_{2}$ fixing abilities than Azotobacter. Similar results were obtained by Tanvir et al. (2017). Among 
Azotobacter sp., A.beijerinckii $\mathrm{N}$-fixation was high ( $7.6 \mathrm{~N} \mathrm{mg} / \mathrm{g}$ ) which is comparable to results of Upadhyay et al. (2015) who reported that $A$. chroococcum $\mathrm{N}_{2}$ fixation was high compared to $A$. beijerinckii.

Based on the performed study of isolation and identification of free $\mathrm{N}$-fixing bacteria Azospirillum and Azotobacter species were identified as Azospirillum lipoferum, A. brasilense, A. dobereinerae, A. zeae and Azotobacter chroococcum, A. beijerinckii and A. salinestris. The microbial activities were naturally distributed in the soil rhizosphere of Acacia species in the Riyadh region. Azospirillum dobereinerae and Azospirillum zeae were identified for the first time in Saudi Arabia. Isolates showed variation among species and their characters. The two genera, Azospirillum and Azotobacter are active in the maintenance of soil fertility and productivity of vegetation. Isolation, purification and screening for highly efficient $\mathrm{N}$-fixers from natural vegetation preparation need further research to find better inoculants. Further, identification of Azospirillum dobereinerae and Azospirillum zeae need to be confirmed by means of molecular technique.

\section{References}

Ahmad E, Zaidi A and Khan MS 2016. Effects of plant growth promoting rhizobacteria on the performance of preengram under field conditions. Jordan J. Biol. Sci. 9: 79-88

Ajmal M, Ali HI, Saeed R, Akhtar A, Tahir M, Mehboob MZ and Ayub A 2018. Biofertilizer as an Alternative for Chemical Fertilizers. Res. and Rev.: J. Agric. Allied Sci. 7: 1-7.

Akhter MS, Hossain SJ, Amir Hossain SK and Datta RK 2012. Isolation and characterization of salinity tolerant Azotobacter sp. Greener J. Biol. Sci. 2: 43-51.

Alatar AA, El-Sheikh MA, Thomas J, Hegazy AK and El Adawy HA 2015. Vegetation, floristic diversity, and size-classes of Acacia gerrardii in an arid wadi ecosystem. Arid Land Research and Management. 29: $335-59$.

Alnohait FA 2015. Diversity and activity of microorganisms in the rhizosphere of some wild plants in Riyadh region. PhD diss., King Saud University. p. 170.

Atlas RM 2010. Handbook of microbiological media, Boca Raton, CRC Press pp. 151 eBook ISBN 9781439804087.

Bashan Y and De-Bashan LE 2010. How the plant growth-promoting bacterium Azospirillum promotes plant growth - A critical assessment. Adv. Agron. 108: 77-136.

Bhardwaj D, Ansari MW, Sahoo RK, Tuteja N 2014. Biofertilizers function as key player in sustainable agriculture by improving soil fertility, plant tolerance and crop productivity. Microb. Cell Fact. 13: 6676.

Boukhatem ZF, Merabet C, Bekki A, Sekkour S, Domergue O, Dupponois R, Galiana A 2016. Nodular bacterial endophyte diversity associated with native Acacia spp. in desert region of Algeria. Afr. J. of Microbil. Res. 10: 634-645.

Cappuccino JG and Welsh CT 2017. Microbiology: A Laboratory Manual, Global Edition. 11th. Ed., Pearson Higher Ed USA.http://lib.hpu.edu.vn/handle/123456789/29242.

Cassán FD, Okon Y and Creus CM. 2015. Handbook for Azospirillum: Technical Issues and Protocols, C.M. Creus, ed. Switzerland: Springer International. doi:10.1007/978-3-319-06542-7.

Chari RD, Reddy RS and Trimaurtulu S 2015. Screening anf Characterization of Diazotrophic Bacteria isolates for Plant Growth Promoting Properties, Int. J. Curr. Microbiol. Appl. Sci. 4: 704-710.

da Silva L, Olivares FL, de Oliveira R, Vega MRG, Aguiar NO and Canellas LP 2014. Root exudate profiling of maize seedlings inoculated with Herbaspirillum seropedicae and humic acids. Chem. Biol. Technol. Agric. 1: 1-18.

Eckert B, Weber OB, Kirchhof G, Halbritter A, Stoffels M and Hartmann A 2001. Azospirillum doebereinerae sp. nov., a nitrogen-fixing bacterium associated with the C4-grass Miscanthus. Int. J. Syst. Evol. Microbiol. 51:17-26. 
Garrity GM, Bell JA and Lilburn T 2005. Class I. Alphaproteobacteria class. nov. In: Brenner DJ, Krieg NR, Staley JT, Garrity GM. Bergey's Manual of Systematic Bacteriology Volume 2: The Proteobacteria Part C (The Alpha-, Beta-, Delta- and Epsilonproteobacteria (2nd ed.). Springer. p. 1.doi:10.1002/ 9781118960608.cbm00041.

Glick BR 2012. Plant Growth-Promoting Bacteria: Mechanisms and Applications.Scientifica. http://dx.doi. org/10.6064/2012/963401.

Hossain MM, Akter S, Hasan MM, Hasan A, Uddin KR, Parvin A, Jahan I, Rahman MN and Rahman SMB 2014. Nitrogen fixing efficiency and physiological characteristics of Azospirillum isolates from the paddy fields of North Bengal, Jahang.Univ. J. Biol. Sci. 3: 47-53.

Jiménez DJ, Montaña JS and Martínez MM 2011. Characterization of free nitrogen fixing bacteria of the genus Azotobacter in organic vegetable-grown Colombian soils. Brazil. J. Microbol. 42: 846-858.

Kanimozhi K and Panneerselvam A 2010. Studies on isolation and nitrogen fixation ability of Azospirillum spp. isolated from Thanjavur district. Der Chemica Sinica 1: 138-145.

Lavrinenko K, Chernousova E, Gridneva E, Dubinina G, Akimov V, Kuever J, Lysenko A and Grabovich M 2010. Azospirillum thiophilum sp. nov., a novel diazotrophic bacterium isolated from a sulfide spring. Int. J. Syst. Evol. Microbiol. 60: 2832-2837 10.1099/ijs.0.018853-0.

Lin SY, Shen FT and Young CC 2011. Rapid detection and identification of the free-living nitrogen fixing genus Azospirillum by 16S rRNA-gene-targeted genus-specific primers. Antonie van Leeuwenhoek. 99: 837-844. doi: 10.1007/s10482-011-9558-1.

Mazinani Z and Asgharzadeh A 2014. Genetic diversity of Azotobacter strains isolated from soils by amplified ribosomal DNA restriction analysis. Cytol. Genet.48: 293-301.

Mazinani Z, Aminafshar M, Asgharzadeh A and Chamani M 2012. Different methods for isolation and preliminary identification of Azotobacter. Int. J. of Agric. Sci. Res. 3: 1-80.

Morais TPD, Brito CHD, Brandão AM and Rezende WS 2016. Inoculation of maize with Azospirillum brasilense in the seed furrow. Revista Ciência Agronômica 47: 290-298.

Narendran RR, Begum SM and Aravindan K 2016. Molecular Identification of Azotobacter chroococcum Isolated From Different Wastes. J. Microbiol. Biotech. Res. 6: 22-26.

Naz I, Bano A, Rehman B, Pervaiz S, Iqbal M, Sarwar A and Yasmin F 2012. Potential of Azotobacter vinelandii Khsr1 as bio-inoculant. Afr. J. Biotech.11: 10368-10372.

Pandiarajan G, Balaiah NT and Kumar BM 2012. Exploration of different Azospirillum strains from various crop soils of Srivilliputtur Taluk. J Biofertil. Biopestici. 3: 117. doi:10.4172/2155-6202.1000117.

Patel PH, Patel JP and Bhatt SA 2013. Characterization and phylogenetic relatedness of Azotobacter salinestris. J. Microbiol. Biotech. Res. 3: 65-70.

Raffi MM and Charyulu PBBN 2012. Nitrogen fixation by the native Azospirillum sp. isolated from rhizosphere and non-rhizosphere of foxtail.Asian J. Biol. life Sci. 1: 213-218.

Rasool S, Sharma B and Rasool S 2015. Isolation and characterization of Rhizobium sp. from a wild legume from BGSBU campus of district Rajouri, J\&K. Int. J. Agric. Sci. 5: 407-413.

Rawat AK, Rao DLN and Sahu RK 2012. Effect of soybean inoculation with Bradyrhizobium and wheat inoculation with Azotobacter on their productivity and $\mathrm{N}$ turnover in a Vertisol.Archives Agron. Soil Sci. 59: 1559-1571.

Reis VM, Baldani VLD and Baldani JI 2015. Isolation, identification and biochemical characterization of Azospirillum spp. and other nitrogen-fixing bacteria. In: Handbook for Azospirillum. Switzerland: Springer International Publishing. p. 3-26.

Rojas A, Castellanos T and Díaz De León J 2013. Genetic variation in wheat for Azospirillum brasilense to adhere to the seedling root. Cereal Res. Comm. 41: 275-283.

Saharan BS and NehraV 2011. Plant growth promoting rhizobacteria: a critical review. Life Sci. Med. Res. 21: $1-30$.

Sahoo RK, Ansari MW, Pradhan M, Dangar TK, Mohanty S and Tuteja N 2014. Phenotypic and molecular characterization of native Azospirillum strains from rice fields to improve crop productivity. Protoplasma. 251: 943-953. 
Saikia SP, Bora D, Goswami A, Mudoi KD and Gogoi A 2013. A review on the role of Azospirillum in the yield improvement of non leguminous crops. Afr. J. Microbiol. Res. 6: 1085-1102.

Sant'Anna FH, Almeida LGP, Cecagno R, Reolon LA, Siqueira FM, Machado MRS, Vasconcelos ATR and SchrankIS 2011. Genomic insights into the versatility of the plant growth-promoting bacterium Azospirillum amazonense. BMC Genomics. 12: 409.

Stella M and Suhaimi M 2010. Selection of suitable growth medium for free-living diazotrophs isolated from compost. J. Trop. Agric. Fd. Sci. 38: 211-219.

Suliman KL, Barakah FN and Assaeed AM 2017. Structural colonization of arbuscular mycorrhizal fungi in three acacia species of different sizes in Riyadh, Saudi Arabia. International Journal of Biosciences. 10: 308-318.

Tanvir R, Javeed A and Bajwa AG 2017. Endophyte bioprospecting in South Asian medicinal plants: an attractive resource for biopharmaceuticals. Appl. Microbiol. Biotech. 101: 1831-1844.

Upadhyay S, Kumar N, Singh V and Singh A 2015. Isolation, characterization and morphological study of Azotobacter isolates. J. Appl. Nat. Sci. 7: 984-990.

Usha DK and Kanimozhi K 2011. Isolation and characterization of saline tolerant Azospirillum strains from paddy field of Thanjavur district. Adv. Appl. Sci. Res. 2: 239-245.

Xie CH and Yokota A 2005. Azospirillum oryzae sp. nov., a nitrogen-fixing bacterium isolated from the roots of the rice plant Oryza sativa. Int. J. Syst. Evol. Microbiol. 55: 1435-1438.

Yorukce MA, Aktaş B, Geroğlu Y, Poyrazoğlu E and Biyik HH 2017. Isolation and Identification of Bacteria from Fruit Garden Soils in Aydın Province. Int. J. Second. Metabol.4: 66-73.

Yousefi S, Kartoolinejad D, Bahmani M and Naghdi R 2017. Effect of Azospirillum lipoferum and Azotobacte rchroococcum on germination and early growth of hopbush shrub (Dodonaea viscosa L.) under salinity stress. J. Sustain. For. 36: 107-120.

(Manuscript received on16 May, 2018; revised on 28 December, 2018) 